\title{
Economic Growth and Foreign Direct Investment in the United States: A Granger Causality Analysis
}

\author{
Serdar ÖZTÜRK* $\quad$ Seher SULUK ${ }^{* *}$
}

\begin{abstract}
Economic, social, political, cultural and technological changes have emerged in the process of with the accelerating of globalization, expanding technological development and developing humanity. One of the most significant developments in the globalization process is the liberalization of international trade. In addition, it can be said there has been an increase in foreign direct investments due to the globalization. In parallel, the relationship between foreign direct investment and economic growth has been a significant research topic in the literature. Therefore, in this study, the causal relationship between foreign direct investment and economic growth is empirically investigated for the United States, which is one of the largest recipient of FDI. In order to reach this aim, firstly, Augmented Dickey-Fuller (ADF) unit root test has been performed by using data belonging to 1970-2018 period and then, Granger causality test was applied. In consequence of the performed econometric analysis, foreign direct investment was found to give rise to economic growth.

Key Words: Economic Growth, Foreign Direct Investment, Granger Causality Analysis JEL Classification: F21, F43, C32
\end{abstract}

\section{ABD'de Ekonomik Büyüme ve Doğrudan Yabancı Yatırım: Granger Nedensellik Analizi}

$\ddot{O} Z$

Küreselleşmenin hız kazanması, teknolojik gelişsiminin yaygınlaşması ve insanlığın gelişsimi süreci içerisinde ortaya ekonomik, sosyal, politik, kültürel ve teknolojik değişimler çıkmıştır. Küreselleşme sürecinde yaşanan en önemli gelişmelerden biri ise uluslararast ticaretin serbestleştirilmesidir. Ayrıca küreselleşmeyle birlikte doğrudan yabancı yatırımlarda bir artış meydana geldiği söylenebilir. Buna paralel olarak, doğrudan yabancı yatırım ile ekonomik büyüme ilişkisi literatürde önemli bir araştırma konusu olmuştur. Bundan dolayl, bu çalışmada, en büyük doğrudan yabancı yatırım alıcısından biri olan ABD için doğrudan yabancı yatırımlar ve ekonomik büyüme arasındaki sebep-sonuç ilişkisi ampirik olarak incelenmiştir. Bu amaca ulaşmak için 19702018 dönemine ait veriler kullanılarak öncelikle Genişletilmiş Dickey-Fuller (ADF) birim kök testi yapılmıs, daha sonra Granger nedensellik testi uygulanmıştır. Uygulanan ekonometrik analizin sonucunda, doğrudan yabancı yatırımların ekonomik büyümeye neden olduğu saptanmıştır.

Anahtar Kelimeler: Ekonomik Büyüme, Doğrudan Yabancı Yatırım, Granger Nedensellik Analiz

JEL Sinıflandirmast: F21, F43, C32

${ }^{*}$ Prof.Dr., Nevşehir Hacı Bektaş Veli University, Department of Economics, E-mail:
serdarozturk@ nevsehir.edu.tr, ORCID Bilgisi: 0000-0003-0650-0244
${ }^{* *}$ Candidate in Economics, Nevşehir Hac1 Bektaş Veli University, Social Sciences Institute, E-mail:
sehersuluk119@gmail.com, ORCID Bilgisi: 0000-0002-3253-1098 


\section{INTRODUCTION}

The concept of globalization is a multi-dimensional concept which shows itself in all areas and affecting everyone in every field (Öztürk \& Sözdemir, 2010: 2156). It can be said that with the phenomenon of globalization, a world that integrates economically, politically, cultural, social and technological is now being formed (Eriksen, 2014: 1). One of the most significant developments in the process of economic globalization is the increase in interdependence and cooperation among countries due to intensive commercial activities due to the liberalization of international trade and the free movement of capital among borders (Kivilcim, 2013: 224). Thus, foreign direct investment has become a substantial factor in the global economy and the increase in foreign capital has been observed (Carlsen \& Jensen, 2008: 50).

Foreign capital can be divided in two as foreign direct investments and portfolio investments. Portfolio investments are realized by foreign investors purchasing valuable papers in international capital markets in order to obtain interest income (Bostan et al., 2016: 25). Foreign direct investment can be defined as the establishment of a production facility in countries outside its headquarters or purchasing existing production facilities in order to spread the production of a company beyond the borders of the country where it is established. Foreign direct investment is an international investment that is made by a direct investor located in a certain location and to establish a long-run and permanent economic bond for an enterprise. In other words, foreign direct investment is the transfer of investment resources to another country by individuals and organisations (Karagöz, 2007: 930). Foreign direct investment is a long-term foreign investment (Özcan \& Ar1, 2010: 67). The subject of foreign direct investment can be addressed bilaterally as the host country (the country invested in) and the investor country. Considering the host country, it can achieve many benefits such as contribution to the national income, utilizing natural resources, creating job opportunities, improving production and management information and reducing foreign trade deficit (Taşdemir \& Ertaş, 2018: 141). According to the general opinion, foreign direct investment influences host country's economic growth positively. Because foreign direct investment have significant impacts in terms of foreign trade, development level and employment. In addition to these, it is the locomotive position in terms of economic growth, technology and the use of information (Erdoğan, 2017: 78). They can also help mobilize entrepreneurs along with capital as well as taking other opportunities such as technology, new management techniques and new channels of access to world markets. The host country seeks to provide some economic and social benefits through foreign investment (Kurtaran, 2007: 367; Nur \& Dilber, 2017: 20). At the same time, foreign direct investment, which is also considered as one of the main engines of economic growth may cause: 1) inward foreign direct investment may increase capital formation and employment augmentation, 2) foreign direct investment may encourage manufacturing exports, 3) foreign direct investment may bring into host economies special resources such as management know-how, skilled labor access to international production networks, and founded 
brand names and 4) foreign direct investment may result in technology transfers and spillover impacts (Zhang, 2006: 3-4).

It can be said that the beginning of foreign capital investments goes back to the investments made in Britain in the 18th century for the extraction of raw materials, precious materials and oil that needed (Çütçü \& Kan, 2018: 3). Capital flows intensified in the late 19th and early 20th centuries. In 1914, more than half of the international investments made up the investment of Great Britain. $90 \%$ of these investment were portfolio investments based on interest rate differences (Yaşar, 2011: 66). When globalization powers emerged after World War II, foreign direct investment gained importance and the expansion of foreign direct investment really took off (Nayak \& Choudhury, 2014: 2). Foreign direct investments slowed down with the outbreak of the oil problem in the world and most of existing investments originated from America (Aydemir et al., 2012: 73). Specially, the foreign direct investment inflow increased rapidly around the world in the $1980 \mathrm{~s}$ and 1990s (Mahmoodi \& Mahmoodi, 2016: 938). Liberal policies, deregulation studies and international trade flows, which were gradually spreading in the world economy in the 1980s, had a major impact on investments. It can be said that in this period, foreign direct investment activities increased globally (Yalman \& Koşaroğlu, 2017: 193).

There are a range of elements that effect foreign direct investment. Some of these are; political factors, institutional factors, cultural factors and economic factors. Accordingly, when making a foreign direct investment decision, it decides whether the country or sector is suitable for investment by taking into consideration some political and economic condition of the country in which it will invest. Countries with economic stability and political stability are more preferred for foreign direct investment inflow, since economic growth performance, the profit they can get and low risks in host countries are important for investors (Sofuoğlu et al., 2019: 342). Some factors influencing foreign direct investment are given in table 1 .

Table 1: Factors Affecting Foreign Direct Investment

\begin{tabular}{|c|c|c|c|}
\hline Political Factors & $\begin{array}{c}\text { Institutional } \\
\text { Factors }\end{array}$ & Cultural Factors & Economic Factors \\
\hline Political stability & $\begin{array}{c}\text { Economic } \\
\text { independence }\end{array}$ & Religious beliefs & Market-seeking \\
\cline { 3 - 4 } Political regime & $\begin{array}{c}\text { Legal and } \\
\text { institutional } \\
\text { Tnfrastructure }\end{array}$ & Cultural closeness & $\begin{array}{c}\text { Market size and per capita } \\
\text { income }\end{array}$ \\
& Bureaucratic quality & Ethical values & Market growth \\
& & & $\begin{array}{c}\text { Access to regional and global } \\
\text { markets }\end{array}$ \\
& & & $\begin{array}{c}\text { Country-specific consumer } \\
\text { preferences }\end{array}$ \\
& & & $\begin{array}{c}\text { Structure of markets } \\
\text { Exchange rate }\end{array}$ \\
& & & Interest rates \\
\hline
\end{tabular}


A Granger Causality Analysis

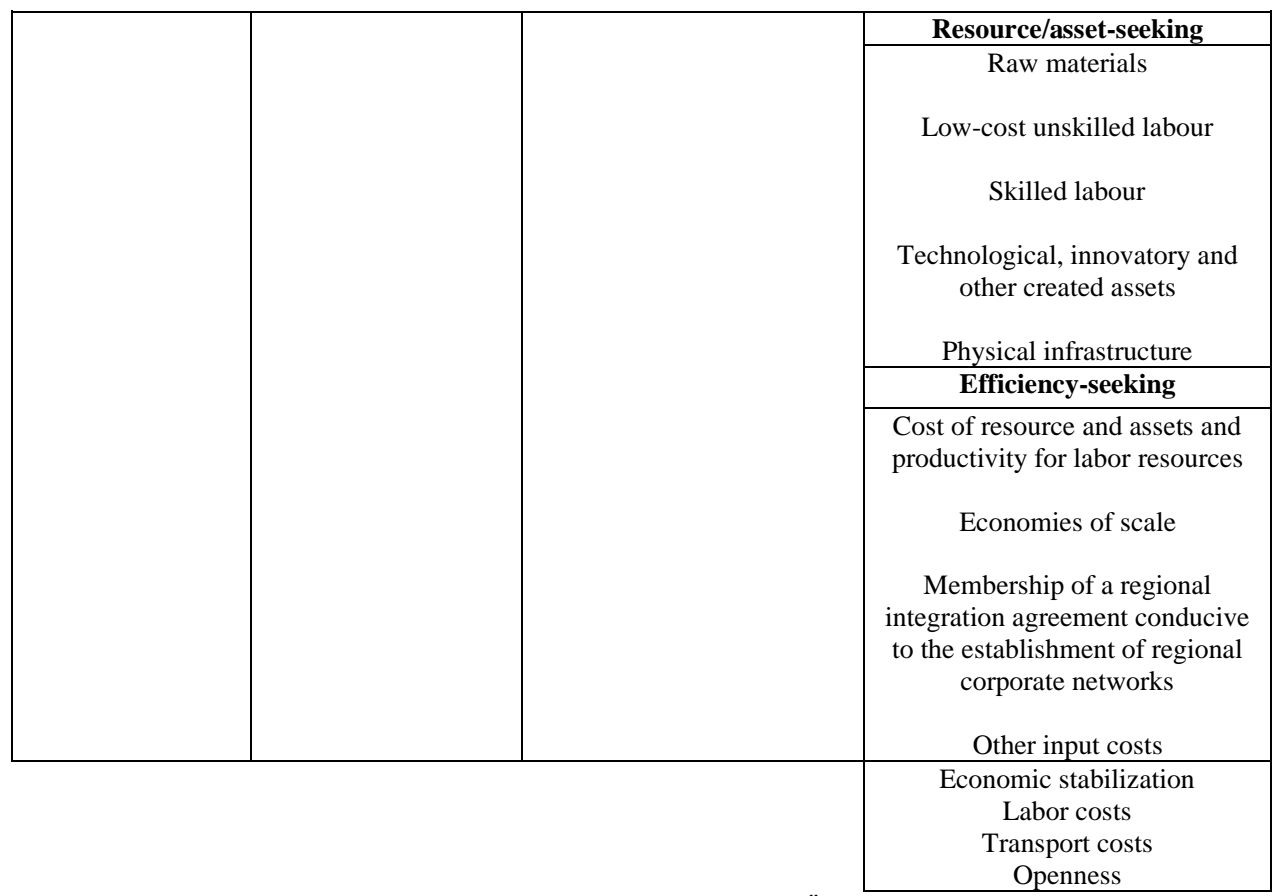

Reference: UNCTAD, World Investment Report 1998: 91; Bayar and Öztürk, 2016: 61-62; Aytekin, 2019: 262.

As one of the largest and most important markets in the world, the United States has remained attractive to foreign investors and foreign firms interested in extending their operations since the beginning of the 1980's (Leopold \& Maniam, 2006: 81). It can be said that this is because that the US has the largest market in the world, the workforce is diverse, capable, innovative and mobile, it has abundant resources and it has the most advanced and efficient financial market (https://www.selectusa.gov). In addition, it has a productive workforce, highly developed infrastructure and a business environment that promotes innovation (https://www.nordeatrade.com). Capital markets in the US are markets where almost all world investors transfer capital (KTO, 2017: 11).

The increase in foreign direct investment has long been regarded as one of the basic drivers of the US economy (Susilo, 2018: 53). The US occupies an important and unique position as the largest investor and the largest recipient of foreign direct investment (Jackson, 2017: 1). As seen in figure 1, despite the decline in foreign direct investment, the US remained the largest recipient of foreign direct investment and followed by China, Hong Kong and Singapore. 
Figure 1: FDI Inflows, Top 20 Host Economies, 2017 and 2018 (Billions of dollars)

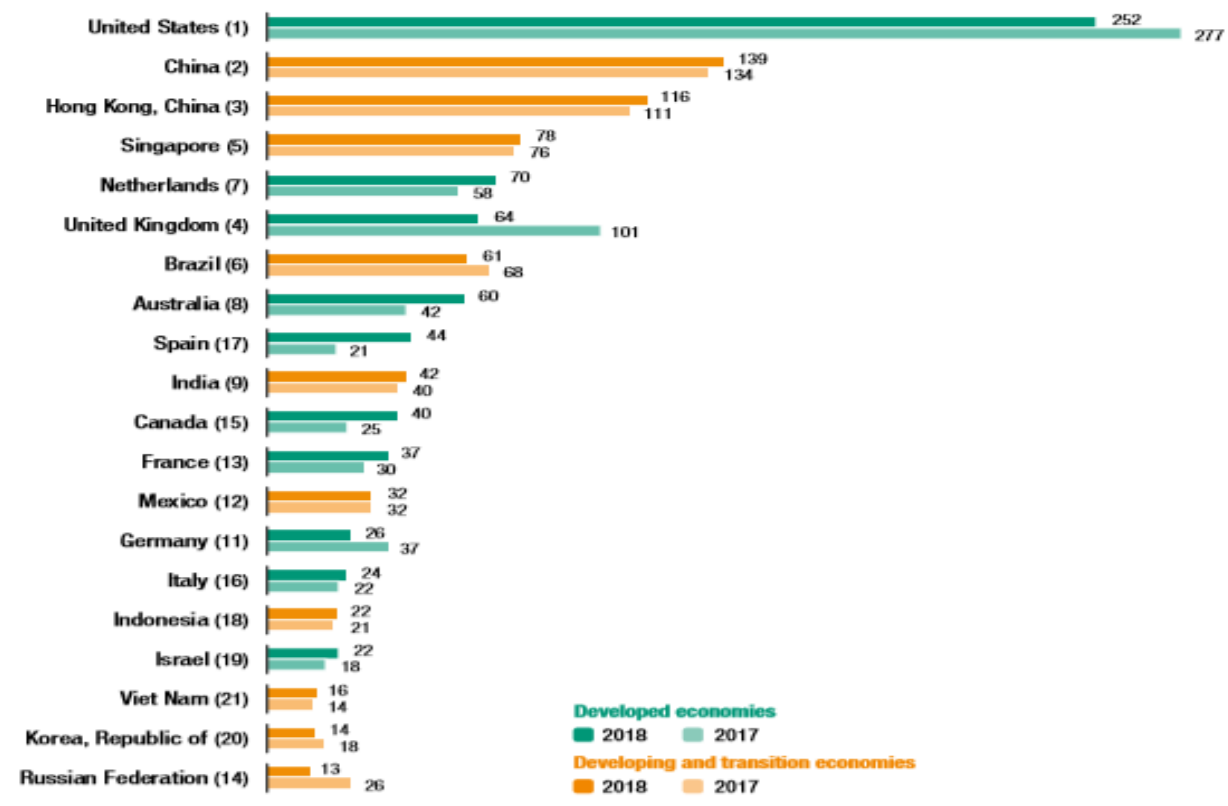

Reference: UNCTAD, World Investment Report 2019, p. 4.

Like many OECD economies, the US trade contracted considerably at the peak of the global crisis. As seen in graph 1 and graph 2, both economic growth and foreign direct investment were negatively affected (OECD, 2017: 2). The foreign direct investment which fell sharply after the 2008 crisis, it started to recover in 2013 and reached its highest level in 2015. But in 2018 the global foreign direct investment dropped 13\% to $\$ 1.3$ trillion (UNCTAD, 2019: 1).

GDP and FDI trends for the United States are shown in the graphs below:

Graph 1: US GDP Growth Rate, \% (2000-2018)

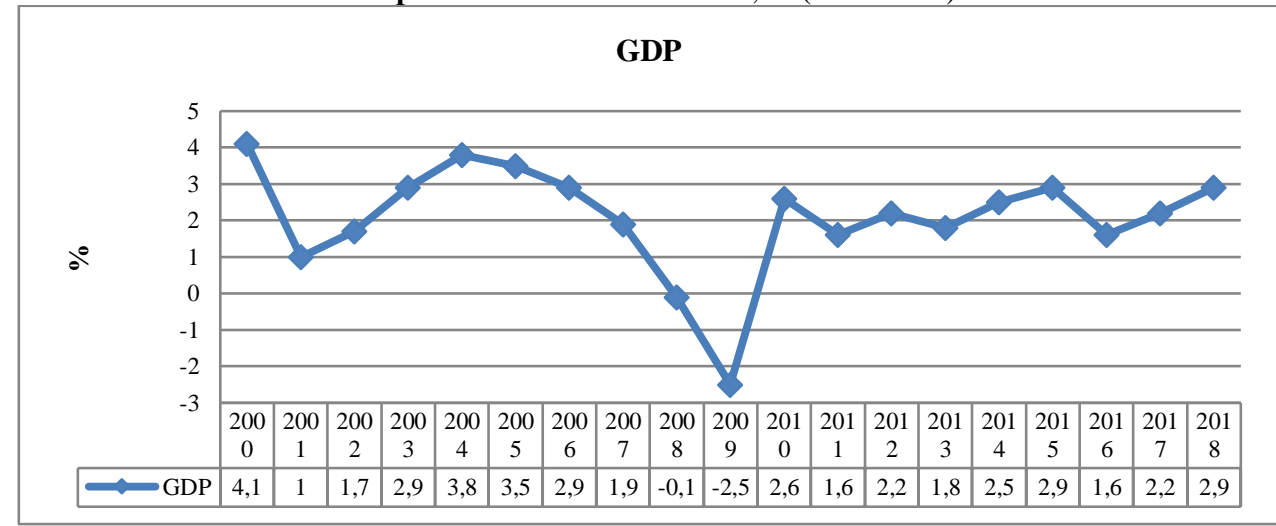

Reference: https://data.worldbank.org, World Bank, WDI.

Graph 1 shows the economic growth rates of the US between 2000-2018. It is seen from the graph that the growth rate of the US is fluctuating after 2009. While the US growth rate was $\% 4,1$ in 2000, it realized as \%2,9 in 2018. The growth rate decreased to negative in 2008-2009. Here, it can be said that it was 
caused by the impact of the economic crises in the world in 2008. The economy has seen a slow uneven recovery since the depths of the recession in 2009 . Hence, in 2010 , it is seen that it gradually started to exit from the crisis and is growing consistent.

Graph 2: US Foreign Direct Investment, billion USD (2000-2018)

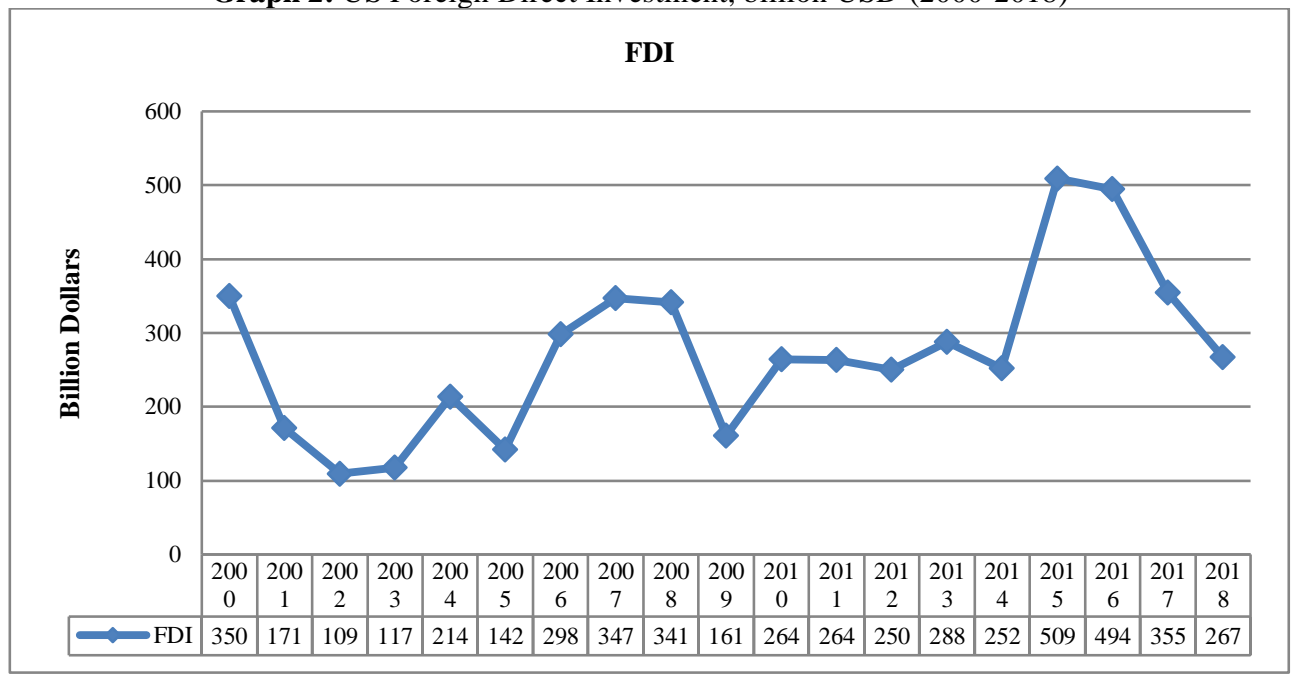

Reference: https://www.theglobaleconomy.com

Graph 2 shows the foreign direct investment of the US between 2000-2018. As seen in the graph, the US foreign direct investment in 2000 was 350 billion dollars. After 2008 foreign direct investment decreased and it realized as 161 billion dollars in 2009. Here, it is seen the impact of the 2008 crisis. Foreign direct investments which followed a fluctuating course between 2009-2014, realized as 509 billion dollars in 2015. Foreign direct investment inflows reached the highest level in 2015 with 509 billion dollars. Even though it was slightly lower with 457,1 billion dollars in 2016, foreign direct investment inflows were the second highest in record level on record in 2016 (Cortez, 2017: 1). Foreign direct investment which gradually decreased in 2015, was realized as 267 billion dollars in 2018. However, despite the decline in foreign direct investment, the US remained the largest recipient of foreign direct investment.

The link between FDI and GDP has been extensively studied, both theoretically and empirically and it is still a hot topic today. According to the general opinion, FDI have a major impact in increasing the economic growth and development performance of countries. Therefore, the main focus point of this study is to reveal the causal relationship and the direction between foreign direct investment and economic growth in the case of the US for the period 1970-2018 by perform Granger causality analysis. In the second part of the study following the introduction, the literature is summarized. In the third section, the data and method to be used in the study are explained and in the fourth part, the empirical results are given and finally, general results are included. 


\section{LITERATURE REVIEW}

There are many studies done on the relationship between GDP and FDI. Here, the relationship between GDP and FDI have been investigated by a lot of researchers for various periods and countries by using different methods and the number of related empirical researches is increasing day by day. In this connection, the studies about the connecting link between GDP and FDI are examined below.

Table 2: Studies on the Relationship between FDI and GDP

\begin{tabular}{|c|c|c|c|}
\hline Researcher & $\begin{array}{c}\text { Scope and } \\
\text { Country/Country } \\
\text { Group } \\
\end{array}$ & Method Used & Conclusion \\
\hline $\begin{array}{l}\text { Dritsaki et al. } \\
\quad(2004)\end{array}$ & $\begin{array}{l}\text { Period between 1960- } \\
2002 \text { for Greece }\end{array}$ & $\begin{array}{l}\text { Cointegration and } \\
\text { Granger causality } \\
\text { analysis } \\
\end{array}$ & $\begin{array}{l}\text { There is a causal link between } \\
\text { FDI and GDP }\end{array}$ \\
\hline $\begin{array}{l}\text { Balamurali \& } \\
\text { Bogahawatte } \\
(2004)\end{array}$ & $\begin{array}{l}\text { Period between 1977- } \\
2003 \text { for Sri Lanka }\end{array}$ & $\begin{array}{c}\text { Johansen cointegration } \\
\text { and Granger causality } \\
\text { tests }\end{array}$ & $\begin{array}{c}\text { There is bilateral causality } \\
\text { between FDI and GDP }\end{array}$ \\
\hline Afşar (2007) & $\begin{array}{l}\text { Period between 1991:1- } \\
\text { 2006:3 for Turkey }\end{array}$ & Granger causality test & $\begin{array}{l}\text { There is an unidirectional } \\
\text { relationship between FDI and } \\
\text { GDP and the direction of this } \\
\text { connecting link is from FDI to } \\
\text { GDP }\end{array}$ \\
\hline $\begin{array}{c}\text { Ozturk \& } \\
\text { Kalyoncu (2007) }\end{array}$ & $\begin{array}{l}\text { Period between } 1975- \\
2004 \text { for Turkey and } \\
\text { Pakistan }\end{array}$ & $\begin{array}{c}\text { Engle-Granger } \\
\text { cointegration and } \\
\text { Granger causality tests }\end{array}$ & $\begin{array}{l}\text { In Pakistan, it is GDP that } \\
\text { causes FDI while in Turkey, } \\
\text { there is a powerful evidence of } \\
\text { a bilateral causality between } \\
\text { GDP and FDI }\end{array}$ \\
\hline Ayaydın (2010) & $\begin{array}{l}\text { Period between 1970- } \\
2007 \text { for Turkey }\end{array}$ & $\begin{array}{c}\text { Johansen-Juselius } \\
\text { cointegration and VAR } \\
\text { causality tests } \\
\end{array}$ & $\begin{array}{c}\text { There is a one-way link from } \\
\text { FDI to GDP }\end{array}$ \\
\hline $\begin{array}{l}\text { Kundan P. \& Gu } \\
\text { (2010) }\end{array}$ & $\begin{array}{c}\text { Period between 1980- } \\
2006 \text { for Nepal } \\
\text { economy }\end{array}$ & $\begin{array}{c}\text { Cointegration and } \\
\text { Granger causality } \\
\text { analysis }\end{array}$ & $\begin{array}{c}\text { There is a long-term } \\
\text { connecting link between FDI } \\
\text { and GDP }\end{array}$ \\
\hline $\begin{array}{l}\text { Lema \& Dimoso } \\
\text { (2011) }\end{array}$ & $\begin{array}{c}\text { Period between 1970- } \\
2007 \text { for Tanzania } \\
\text { economy }\end{array}$ & Granger causality test & $\begin{array}{c}\text { There is two-way causality } \\
\text { between FDI and GDP }\end{array}$ \\
\hline $\begin{array}{c}\text { Gürsoy \& } \\
\text { Kalyoncu (2012) }\end{array}$ & $\begin{array}{l}\text { Period between 1997- } \\
2010 \text { for Georgia }\end{array}$ & $\begin{array}{c}\text { Engle-Granger } \\
\text { cointegration and } \\
\text { Granger causality tests }\end{array}$ & $\begin{array}{c}\text { There is cointegration between } \\
\text { FDI and GDP. According to } \\
\text { the results, in Georgia, FDI } \\
\text { causes GDP }\end{array}$ \\
\hline $\begin{array}{l}\text { Alkhasawneh } \\
\text { (2013) }\end{array}$ & $\begin{array}{c}\text { Period between } 1970- \\
2010 \text { for the state of } \\
\text { Qatar }\end{array}$ & $\begin{array}{l}\text { Johansen cointegration } \\
\text { and Granger causality } \\
\text { tests }\end{array}$ & $\begin{array}{l}\text { There is a long-term } \\
\text { equilibrium link between FDI } \\
\text { and GDP. Furthermore, there is } \\
\text { a two-way causality on the } \\
\text { FDI-GDP relationship }\end{array}$ \\
\hline $\begin{array}{l}\text { Antwi et al. } \\
\text { (2013) }\end{array}$ & $\begin{array}{l}\text { Period between 1980- } \\
2010 \text { for Ghana }\end{array}$ & $\begin{array}{l}\text { Simple ordinary least } \\
\text { square (OLS) } \\
\text { regressions }\end{array}$ & $\begin{array}{l}\text { There is a positive and } \\
\text { significant relationship } \\
\text { between FDI and GDP }\end{array}$ \\
\hline $\begin{array}{l}\text { Gürsoy et al. } \\
\text { (2013) }\end{array}$ & $\begin{array}{l}\text { Period between 1997- } \\
2010 \text { for Azerbaijan, } \\
\text { Kyrgyz Republic, } \\
\text { Kazakhstan, Tajikistan, } \\
\text { Turkmenistan, and } \\
\text { Uzbekistan }\end{array}$ & $\begin{array}{l}\text { Johansen cointegration } \\
\text { and Granger causality } \\
\text { tests }\end{array}$ & $\begin{array}{c}\text { FDI and economic growth } \\
\text { variables are cointegrated for } \\
\text { Azerbaijan and Turkmenistan. } \\
\text { Furthermore, FDI give rise to } \\
\text { GDP for Azerbaijan and two- } \\
\text { way causality is observed for } \\
\text { Turkmenistan }\end{array}$ \\
\hline $\begin{array}{c}\text { Ferrer \& } \\
\text { Zermeno }(2015)\end{array}$ & $\begin{array}{c}\text { Period between } 1995- \\
2012 \text { for China } \\
\text { economy }\end{array}$ & $\begin{array}{l}\text { Cointegration and } \\
\text { causality analysis }\end{array}$ & $\begin{array}{c}\text { There is a relationship between } \\
\text { FDI and GDP. GDP causes an } \\
\text { increase in FDI }\end{array}$ \\
\hline
\end{tabular}


Serdar Öztürk \& Seher Suluk / Economic Growth and Foreign Direct Investment in the United States: A Granger Causality Analysis

\begin{tabular}{|c|c|c|c|}
\hline $\begin{array}{c}\text { Simionescu } \\
\text { (2016) }\end{array}$ & $\begin{array}{c}\text { Period between 2008- } \\
\text { 2014 for European } \\
\text { Union (EU-28) }\end{array}$ & $\begin{array}{c}\text { Panel vector- } \\
\text { autoregressive model } \\
\text { and Bayesian random } \\
\text { effect models }\end{array}$ & $\begin{array}{c}\text { There is a mutual and positive } \\
\text { link between FDI and GDP }\end{array}$ \\
\hline Baig et al. (2016) & $\begin{array}{c}\text { Period between 1991- } \\
\text { 2012 for Pakistan, } \\
\text { Nepal, Bhutan, India } \\
\text { and Maldives }\end{array}$ & $\begin{array}{c}\text { Johansen cointegration } \\
\text { and Granger causality } \\
\text { tests }\end{array}$ & $\begin{array}{c}\text { There is a cointegration and the } \\
\text { Granger test shows that FDI } \\
\text { and GDP in case of Nepal } \\
\text { cause a one-way causality }\end{array}$ \\
\hline $\begin{array}{c}\text { Taşdemir \& } \\
\text { Erdaş (2018) }\end{array}$ & $\begin{array}{c}\text { Period between } \\
\text { Turkey economy }\end{array}$ & $\begin{array}{c}\text { Granger causality test, } \\
\text { Impulse-response } \\
\text { analysis and variance } \\
\text { decomposition analysis }\end{array}$ & $\begin{array}{c}\text { There is an unidirectional } \\
\text { causality from FDI to GDP }\end{array}$ \\
\hline $\begin{array}{c}\text { Öncü \& Çelik } \\
\text { (2018) }\end{array}$ & $\begin{array}{c}\text { Period between 1998- } \\
\text { 2016 for BRICT } \\
\text { countries }\end{array}$ & $\begin{array}{c}\text { Dumitrescu and Hurlin } \\
\text { causality test }\end{array}$ & $\begin{array}{c}\text { There is no causal link from } \\
\text { FDI to GDP but there is a } \\
\text { causal relationship from GDP } \\
\text { to FDI }\end{array}$ \\
\hline
\end{tabular}

\section{THE DATA AND METHOD}

In this study, the relationship between economic growth and foreign direct investment has been applied by using time series. For that purpose, the annual variables of economic growth and foreign direct investment for the period 19702018 were used for the US. The logarithms are taken so that the data are appropriate for analysis. The data are obtained from The World Bank (WDI). Eviews program was used during the analysis phase and first, the Augmented Dickey-Fuller (ADF) unit root test and then Granger causality test have been applied.

The graphs of the series are given below.

\section{Graph 3: GDP and FDI}

GDP

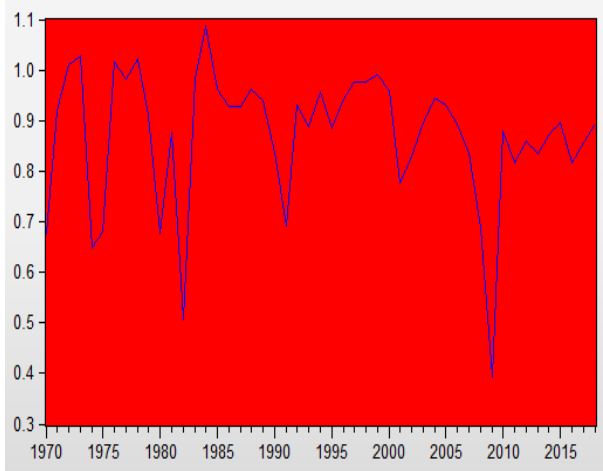

INVESTMENT

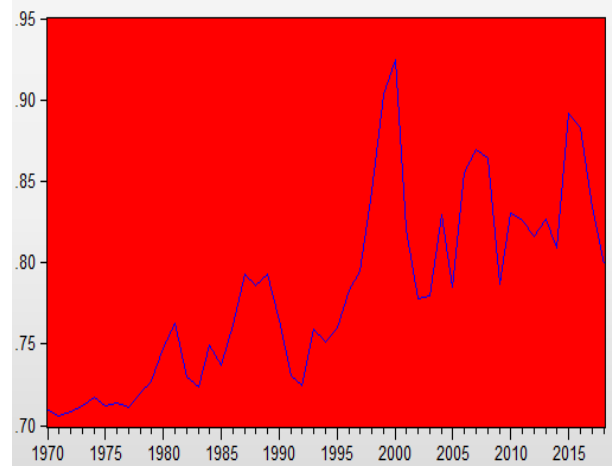

Once all the data have been subjected to unit root testing, it is useful to examine whether there is a causal relationship between these variables. Therefore, after determining that the series are stationary at the same level and the lag length was determined, in the second stage, Granger causality test was performed.

\section{EMPIRICAL RESULTS}

In this study, to investigate the causality between economic growth and foreign direct investment and its direction in the US economy between 1970 and 2018, Granger causality test was applied. But before performing Granger causality test, Augmented Dickey-Fuller (ADF) unit root test was performed to the series. This is because, many economic time series are known to contain unit root. 
Therefore, in order to determine the most suitable equation to be used in the analysis of the data, it is essential to examine whether the time series used are stationary. In other words, in order to have a meaningful link between the two variables, the variables should be stationary. In the case of non-stationary series, false regression will be a problem. Therefore, the analysis between the series can be really deviant and misleading (Taşdemir \& Erdaş, 2018: 145). For this reason, in order to analyze the stationary of the series, ADF test has been applied.

The hypothesis of the ADF unit root test is as follows (Nell \& Zimmermann, 2011):

$\mathrm{H}_{0}$ : The series is not stationary, unit contains root.

$\mathrm{H}_{1}$ : The series is stationary, unit does not contain root.

In this study, the functional formula of the studied variable is proposed as follows:

$$
G D P=f\left(F D I_{t}\right)
$$

In the formula, GDP is economic growth and FDI expresses foreign direct investment.

Table 3: ADF Unit Root Test Results

\begin{tabular}{|c|l|l|l|l|}
\hline \multicolumn{2}{|c|}{ Variables-Method } & \multicolumn{2}{c|}{ Intercept } & \multicolumn{2}{c|}{ Trend and Intercept } \\
\hline Economic Growth (GDP) & \multicolumn{2}{c|}{ Prob. } & t-Statistic & Prob. \\
\hline ADF & t-Statistic & Prob. & -5.703250 & 0.0001 \\
\hline 1. Difference & -5.624404 & 0.0000 & -9.176527 & 0.0000 \\
\hline Foreign Direct Investment (FDI) & -9.290247 & 0.0000 & t-Statistic & Prob. \\
\hline ADF t-Statistic & Prob. & -3.563311 & 0.0439 \\
\hline 1. Difference & -2.299458 & 0.1763 & -6.646353 & 0.0000 \\
\hline
\end{tabular}

Table 3 shows the ADF unit root test results. As seen from the variables, economic growth is stationary at the level. But, as seen at the table, the series belonging to foreign direct investment is not stationary in level value. It becomes stationary when first differences are taken. Consequently, the variables do not contain unit root. After analyzing the stationary of the variables, Granger causality test was implemented to determine whether there is a causal connecting link between the series. But before the Granger causality analysis, optimal lag length criteria must be found. In table 4 , the lag length criteria has been examined and determined to 1 .

Table 4: Lag Length Criteria

\begin{tabular}{|c|c|c|c|c|c|c|}
\hline Lag & Logl & LR & FPE & AIC & SC & HQ \\
\hline 0 & 93.41408 & NA & $5.90 \mathrm{e}-05$ & -4.062848 & -3.982552 & -4.032915 \\
\hline 1 & 122.8354 & $54.91983^{*}$ & $1.91 \mathrm{e}-05^{*}$ & $-5.192685^{*}$ & $-4.951797^{*}$ & $-5.102885^{*}$ \\
\hline 2 & 123.1553 & 0.568612 & $2.25 \mathrm{e}-05$ & -5.029123 & -4.627642 & -4.879455 \\
\hline 3 & 124.3702 & 2.051951 & $2.55 \mathrm{e}-05$ & -4.905344 & -4.343271 & -4.695809 \\
\hline 4 & 126.6375 & 3.627633 & $2.77 \mathrm{e}-05$ & -4.828334 & -4.105669 & -4.558931 \\
\hline
\end{tabular}

Following this transaction, Granger causality analysis have been performed to test whether there is a link between economic growth and foreign direct investment in US economy. The equation of the model of Granger causality test is as follows (Granger, 1969: 431): 
Serdar Öztürk \& Seher Suluk / Economic Growth and Foreign Direct Investment in the United States: A Granger Causality Analysis

$$
\begin{aligned}
& X_{t}=\sum_{j=1}^{m} a_{j} X_{t-j}+\sum_{j=1}^{m} b_{j} Y_{t-j}+\varepsilon_{t}, \\
& Y_{t}=\sum_{j=1}^{m} c_{j} X_{t-j}+\sum_{j=1}^{m} d_{j} Y_{t-j}+\eta_{t},
\end{aligned}
$$

The Granger causality test have been first of all proposed by Granger. Granger causality test is a widely used test to examine causality relationship between two time series variable. Therefore, it was tried to determine whether foreign direct investment and economic growth influence one another with the help of Granger causality test. Accordingly, the equations of causality between the two variables are expressed below:

Model of foreign direct investment as a cause of economic growth:

$$
G D P_{i, t}=a_{0}+\sum_{i=1}^{m} a_{i} G D P_{t-1}+\sum_{i=1}^{m} b_{i} F D I_{t-1}+u_{i, t}
$$

Model that economic growth is the cause of foreign direct investment:

$$
F D I_{i, t}=a_{0}+\sum_{i=1}^{m} a_{i} F D I_{t-1}+\sum_{i=1}^{m} b_{i} G D P_{t-1}+u_{i, t}
$$

The analysis of the variables is given in table 5 .

Table 5: Granger Causality Test Results

\begin{tabular}{|c|c|c|}
\hline Dependent Variable: GDP & df & Prob. \\
\hline FDI & 1 & 0.0464 \\
\hline All & 1 & 0.0464 \\
\hline & & Result: $\mathrm{H}_{0}$ reject, $\mathrm{H}$ alternative accept \\
\hline Dependent Variable: FDI & & 0.4402 \\
\hline GDP & 1 & 0.4402 \\
\hline All & 1 & Result: $\mathrm{H}_{0}$ accept, $\mathrm{H}$ alternative reject \\
\hline
\end{tabular}

According to Granger causality test performed by using yearly data covering the period 1970-2018 for the US, economic growth is not the cause of FDIs because the probability value is more than 0.05 . However, when we determine the dependent variable as GDP, the probability value is 0.0464 . Accordingly, there is a causality relationship from FDI to GDP.

\section{FDI

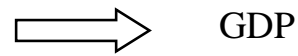

\section{CONCLUSION}

As known, globalization has started to affect all countries of the world. In this way, foreign direct investment has become a significant factor in the global economy and an increase in foreign capital has been observed. Foreign direct investment is the investment of a firm or individual in one country for commercial purpose in another country. According to the general opinion, foreign investment influence the economic growth of the host country positively. Because foreign direct investments have important effects in terms of utilizing natural resources, foreign trade, creating job opportunities, employment, improving production and 
management information, reducing foreign trade deficit, increasing economic growth performance, development and the use of technology and knowledge. The United States is one of the countries that attract the most foreign investment. The analysis of the graphics shows that foreign direct investment in the US has increased sharply in 2015 since 2000. However, although foreign direct investments decreased from 2015 to 2018, the US continues to be one of the largest recipient of foreign direct investment. In the literature, many studies examining whether there is a relationship between economic growth and foreign direct investment have been conducted and very different results have been achieved in the analysis. Different econometric methods were applied in the studies and the findings obtained differed according to the methods used. In this context, in this study, the connection between foreign direct investment and economic growth for the US is examined. In the study, data between 1970-2018 period has been used. All data are logarithmic. First of all, Augmented Dickey-Fuller (ADF) unit root test which is widely used in time series was applied on the series. After the data were made stationary, Granger causality analysis was performed. As a result of Granger causality test, while foreign direct investment is a cause of economic growth, economic growth is not a reason of foreign direct investment. Therefore, Granger causality analysis concluded that there is an unidirectional connection from foreign direct investment to economic growth. Accordingly, when the empirical findings are evaluated in this study where the relationship between economic growth and foreign direct investments is analyzed, it is seen that the opinion that foreign direct investments, which are common in the literature, affect the economic growth in the US positively is valid. This result have parallels with some studies in the literature. When the obtained results are evaluated in general, it is concluded that foreign direct investments are very important for economic growth for the US economy. Therefore, policy makers can work to improve the business and investment environment and they can pay more attention to the overall role and quality of foreign direct investment. Besides, as foreign direct investments are an essential determinant of economic growth in the US, policy makers can further support innovation, further improve labor and research and development activities and they can encourage foreign investors to contribute to new products and new technologies. Foreign direct investments are quite important as they also create employment as they will provide more business areas as well as economic growth.

\section{REFERENCES}

Afşar, M. (2007). The Causality Relationship between Economic Growth and Foreign Direct Investment in Turkey. Selçuk Üniversitesi Sosyal Bilimler Enstitüsü Dergisi, Sayı: 20, pp. $1-9$.

Alkhasawneh, M. F. (2013). The Granger Causality Relationship between Foreign Direct Investment (FDI) and Economic Development in the State of Qatar. Applied Mathematics \& Information Sciences, 7(5), pp. 1767-1771.

Antwi, S., Mills, E. F., Mills, G. A. \& Zhao, X. (2013). Impact of Foreign Direct Investment on Economic Growth: Empirical Evidence from Ghana. International Journal of Academic Research in Accounting, Finance and Management Science, 3(1), pp. 18-25. 
Ayaydın, H. (2010). Doğrudan Yabancı Yatırımlar İle Ekonomik Büyüme Arasındaki İlişkinin İncelenmesi: Türkiye Örneği. Sayı: 26, Dumlupınar Üniversitesi Sosyal Bilimler Dergisi.

Aydemir, C., Arslan, İ. \& Uncu, F. (2012). Doğrudan Yabancı Yatırımların Dünya'daki ve Türkiye'deki Gelişimi, Kocaeli Üniversitesi Sosyal Bilimler Enstitüsü Dergisi, 23, s. 69104.

Aytekin, G. K. (2019). Doğrudan Yabancı Yatırımlar, Belirleyicileri ve Ekonomik Etkileri, Ufuk Üniversitesi Sosyal Bilimler Enstitüsü Dergisi, Y11: 8, Sayı: 15, s. 255-278.

Balamurali, N. \& Bogahawatte, C. (2004). Foreign Direct Investment and Economic Growth in Sri Lanka. Sri Lankan Journal of Agricultural Economics, 6(1), pp. 37-50.

Bayar, Y. \& Öztürk, Ö. F. (2016). Doğrudan Yabancı Sermaye Yatırımları Girişlerinin Belirleyicileri Üzerine Bir Literatür İncelemesi, International Journal of Applied Economic and Finance Studies, Vol. 1, No. 1.

Bostan, A., Kelleci, S. Ü. \& Yılmaz, A. (2016). Doğrudan Yabancı Sermaye Yatırımları ve Ekonomik Büyüme Arasındaki İlişki: Avrasya Ekonomileri Örneği. MANAS Sosyal Araştırmalar Dergisi, Cilt: 5, Say1: 5, 23-36.

Carlsen, M. \& Jensen, A. M. (2008). Globalisering og Danske Direkte Investeringer. 49-64.

Cortez, M. (2017). Foreign Direct Investment in the United States. U.S. Department of Commerce, Economics and Statistics Administration, p. 1-13.

Çütçü, İ. \& Kan, E. (2018). Doğrudan Yabancı Sermaye Yatırımlarını Etkileyen Faktörler: Türkiye Örneği, Sakarya İktisat Dergisi, 7(3), s. 1-21.

Dritsak, M., Dritsaki, C. \& Adamopoulos, A. (2004). A Causal Relationship between Trade, Foreign Direct Investment and Economic Growth in Greece. American Journal of Applied Sciences, 1(3), pp. 230-235.

Encinas-Ferrer, C. \& Villegas-Zermeño, E. (2015). Foreign Direct Investment and Gross Domestic Product Growth. International Conference on Applied Economics. Procedia Economics and Finance, 24, pp. 198-207.

Erdoğan, S. (2017). Doğrudan Yabancı Yatırımların Makroekonomik Belirleyicileri Üzerine Bir Çalışma: Latin Amerika - Türkiye Karşılaştırması. Marmara Üniversitesi İktisadi ve İdari Bilimler Dergisi, 39(1), ss. 77-100.

Eriksen, T. H. (2014). Globalization. London: Bloomsbury Academic.

Granger, C. W. (1969). Investigating Causal Relations by Econometric Models and Cross-spectral Methods. Econometrica, 37(3), pp. 424-438.

Gürsoy, F. \& Kalyoncu, H. (2012). Foreign Direct Investment and Growth Relationship in Georgia. International Journal of Economics and Financial Issues, 2(3), pp. 267-271.

Gürsoy, F., Sekreter, A. \& Kalyoncu, H. (2013). FDI and Economic Growth Relationship Based on Cross-Country Comparison. International Journal of Economics and Financial Issues, 3(2), pp. 519-524.

Jackson, J. K. (2017). Foreign Direct Investment in the United States: An Economic Analysis. Congressional Research Service.

Karagöz, K. (2007). Türkiye'de Doğrudan Yabancı Yatırım Girişlerini Belirleyen Faktörler: 19702005. Journal of Yaşar University, 2(8), 927-948.

Kıvılcım, F. (2013). Küreselleşme Kavramı ve Küreselleşme Sürecinin Gelişmekte Olan Ülke Türkiye Açısından Değerlendirilmesi. Sosyal ve Beşeri Bilimler Dergisi, 5(1), ss. 219-230.

Konya Ticaret Müdürlügü, KTO. (2017). Amerika Birleşik Devletleri Ülke Raporu, D1ş Ticaret Müdürlüğü, s. 1-39.

Kurtaran, A. (2007). Doğrudan Yabancı Yatırım Kararları ve Belirleyicileri, Atatürk Sosyal Bilimler Enstitüsü Dergisi, Cilt 10, Say1 2, s. 367-382.

Lema, N. C. \& Dimoso, R. (2011). Foreign Direct Investment and Economic Growth in Tanzania: The Granger-Causality Analysis. Uongozi Journal of Management and Development Dynamics, 22(2), pp. 22-37.

Leopold, G. \& Maniam, B. (2006). Foreign Direct Investment in the United States: Country Analysis. Journal of Economics and Economic Education Research. 
Mahmoodi, M. \& Mahmoodi, E. (2016). Foreign Direct Investment, Exports and Economic Growth: Evidence From Two Panels of Developing Countries, Economic Research-Ekonomska Istraživanja, 29:1, pp. 938-949.

MM, B., S., K. \& M., B. (2016). Relationship between FDI and GDP: A Case Study of South Asian Countries. Journal of Business \& Financial Affairs, 5:1, pp. 1-4.

Nayak, D. \& Choudhury, R. N. (2014). A Selective Review of Foreign Direct Investment Theories, Working Paper No. 143.

Nell, C. \& Zimmermann, S. (2011). Summary based on Chapter 12 of Baltagi: Panel Unit Root Tests. Department of Economics at University of Vienna.

Nur, H. B. \& Dilber, İ. (2017). Gelişmekte Olan Ülkelerde Doğrudan Yabancı Yatırımları Belirleyen Temel Unsurlar, Dokuz Eylül Üniversitesi İktisadi ve İdari Bilimler Fakültesi Dergisi, Cilt: 32, Say1: 2, s. 15-45.

OECD. (2017). United States: Trade and Investment Statistical Note. United States.

Öncü, E. \& Çelik, Ş. (2018). Doğrudan Yabancı Yatırımlar ve Ekonomik Büyüme İlişkisi: BRICT Ülkeleri Panel Nedensellik Analizi. Uluslararası İktisadi ve İdari İncelemeler Dergisi, 17. UíK Özel Sayıs1, pp. 403-414.

Özcan, B. \& Arı, A. (2010). Doğrudan Yabancı Yatırımların Belirleyicileri Üzerine Bir Analiz: OECD Örneği, Ekonometri ve Ístatistik, Sayı: 12, s. 65-88.

Öztürk, I. \& Kalyoncu, H. (2007). Foreign Direct Investment and Growth: An Empiricial Investigation Based on Cross-Country Comparison. Economia Internazionale.

Öztürk, S. \& Sözdemir, A. (2010). Küresel Krizin Ekonomik Etkileri: Küreselleşmenin Krizi. Turgut Ozal International Conference on Economics and Politics-1 Global Crises and Economics Governance, pp. 2155-2168.

P., M. K. \& Gu, Q. (2010). A Time Series Analysis of Foreign Direct Investment and Economic Growth: A Case Study of Nepal. International Journal of Business and Management, 5(2), pp. 144-148.

Simionescu, M. (2016). The Relation between Economic Growth and Foreign Direct Investment during the Economic Crisis in the European Union. Zb. rad. Ekon. fak, 34(1), pp. 187-213.

Sofuoğlu, E. Kızılkaya, O. \& Uysal, D. (2019). Ekonomik Özgürlükler ve Doğrudan Yabanc1 Yatırımlar Arasındaki İlişki: Panel Eşbütünleşme Analizi, Business and Economics Research Journal, Vol. 10, No. 2, s. 341-355.

Susilo, D. (2018). The Impact of Foreign Direct Investment on Economic Growth (a Causal Study in the United States). BISE: Jurnal Pendidikan Bisnis dan Ekonomi, 4(1), pp. 50-63.

Taşdemir, D. \& Erdaş, H. (2018). Doğrudan Yabancı Yatırım Ekonomik Büyüme İlişkisi: Türkiye Örneği. Trakya Üniversitesi İktisadi ve İdari Bilimler Fakültesi Dergisi, pp. 140-152.

United Nations (1998). World Investment Report. New York: United Nations Publications.

United Nations (UNCTAD) (2019). World Investment Report. New York: United Nations Publications.

World Bank (2019). https://data.worldbank.org/. Accessed: 7 September 2019.

Yalman, İ. \& Koşaroğlu, Ş. M. (2017). Doğrudan Yabancı Yatırımların Ekonomik Büyüme ve İşsizlik Üzerindeki Etkisi, Uluslararası Ekonomi, İsletme ve Politika Dergisi, 1(2), s. 191-205.

Yaşar, E. (2011). Finansal Liberalizasyon ve Doğrudan Yabancı Yatırımların Global Trendi, Dumlupinar Üniversitesi Sosyal Bilimler Dergisi, Say1: 29, s. 65-86.

Zhang, K. H. (2006). Foreign Direct Investment and Economic Growth in China: A Panel Study for 1992-2004.

https://www.selectusa.gov/why-invest. Accessed: 6 September 2019.

https://www.theglobaleconomy.com/USA/fdi_dollars/. Accessed: 7 September 2019.

https://www.nordeatrade.com/en/explore-new-market/united-states/investment. Accessed: 19

February 2020. 


\section{SUMMARY}

Economic, social, political and technological changes have been shown up in the process of accelerating globalization, expanding technological development and developing humanity. One of the most important developments in the globalization process is the liberalization of international trade. Besides, there has been an increase in foreign direct investment due to the globalization. In this context, foreign direct investment have become an important factor in the global economy and thus an increase in foreign capital has been observed. Different results were obtained in the researches on the effect of foreign direct investment on economic growth. But according to the general opinion, foreign direct investment has a significant effect on economic growth of the country. Because foreign direct investment has important effects on such as foreign trade, employment increase, use of technology and information, development level, economic growth etc. There are several factors that affect foreign direct investment, such as political factors, factors related to investment environment and economic factors. Therefore, when making foreign direct investment decision, a country takes into consideration the political and economic situation of the country it will invest in and accordingly, decides whether it is appropriate to invest. The United States which is one the largest and most important market in the world is also one of the largest recipient of foreign direct investment. The increase in foreign direct investment has long be regarded as one of the driving forces of the United States economy. Therefore, the aim of this study is to empirically examine the causal relationship between foreign direct investment and economic growth for the United States. To achieve this goal, annual data for the period 1970-2018 were used.

Firstly, the conceptual framework and the relationship between economic growth and foreign direct investment are explanied. Then, a comprehensive literature review have been made about foreign direct investment and economic growth. Many studies have been conducted on the relationship between foreign direct investment and economic growth. Generally, researchers have empirically proved that there is a positive relationship between foreign direct investment and economic growth. Accordingly, foreign direct investment is considered to be the determinant of economic growth. Because foreign direct investment play an important role in increasing the economic growth and development performance of countries. After the theoretical part of the study, the whether there is a presence of a causal relationship between foreign direct investment and economic growth in the United States has been examined empirically by applying Granger causality analysis. Annual data of GDP and FDI were used in the analysis and the logarithms of these data were taken. The data used in the research was obtained from The World Bank and Eviews program was used in the analysis phase. In the case of non-stationary series, the wrong regression problem will arise. For this reason, in order to obtain a meaningful result between two variables, it is important that the variables are equally stationary. Within this scope, firstly, Augmented DickeyFuller (ADF) unit root test was used. According to ADF unit root test results, the variables are not stationary at level. Hence, after taking the first differences of the 
variables, the series were made stationary. After determining the lag length criteria, Granger causality test was applied to test the causal relationship between foreign direct investment and economic growth. Granger causality test was first proposed by Granger and is a widely used test to investigate the causality. According to Granger causality test conducted for the United States between 1970-2018, foreign direct investment is a cause of economic growth, whereas economic growth is not a cause of foreign direct investment. In other words, there is a one-way relationship between foreign direct investment and economic growth and the direction of this relationship is from foreign direct investment to economic growth. 